\title{
Metabolic abnormalities and overweight in HIVIAIDS persons-treated with antiretroviral therapy
}

\section{(f}

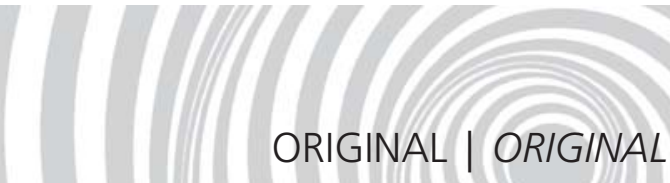

Anormalidades metabólicas e sobrepeso em portadores de HIV/AIDS em terapia com anti-retrovirais

Luísa Helena Maia LEITE ${ }^{1}$

Ana Beatriz de Mattos Marinho SAMPAIO

A B S T R A C T

\section{Objective}

To describe the proportion of overweight among patients with human immunodeficiency virus/Acquired Immune Deficiency Syndrome and correlate overweight and highly active antiretroviral therapy with metabolic complications.

\section{Methods}

A cross-sectional study was conducted among human immunodeficiency virus/Acquired Immune Deficiency Syndrome outpatients undergoing nutritional therapy from 2000 to 2006 in a University Health Center. The sample consisted of 393 human immunodeficiency virus/Acquired Immune Deficiency Syndrome patients. Nutritional and medical records were used as a source of data on personal, clinical and biochemical information. Data analysis included descriptive statistics and the Chi-square test.

\section{Results}

Sixty-nine percent of the patients were males aging from 26 to 49 years. Overweight and obesity were identified in $49 \%$ of this population. The most important metabolic complications were low levels of high-density lipoprotein (70\%) and high levels of triglycerides (48\%) and cholesterol (40\%). Higher body mass index was associated with higher lipid levels and more evidence of insulin resistance.

\section{Conclusion}

This study demonstrated an important proportion of overweight and obesity among human immunodeficiency virus/Acquired Immune Deficiency Syndrome patients. These results suggest that nutritional interventions and lifestyle modifications may be useful strategies to decrease the cardiovascular risk in this population.

Indexing terms: Overweight. Obesity. HIV. Dyslipidemia. Insulin resistance.

\footnotetext{
1 Universidade Federal do Rio de Janeiro, Hospital Escola São Francisco de Assis, Serviço de Assistência ao Portador de HIV/AIDS. Av. Presidente Vargas, 2863, Cidade Nova, 20210-031, Rio de Janeiro, RJ, Brasil. Correspondência para/Correspondence to: L.H.M. LEITE. E-mail:<luisamaia@uol.com.br>.

2 Universidade Federal do Rio de Janeiro, Hospital Escola São Francisco de Assis, Laboratório de Estudos em Política, Planejamento e Assistência em DST/AIDS. Rio de Janeiro, RJ, Brasil.
} 
278 | L.H.M. LEITE \& A.B.M.M. SAMPAIO

\section{RE S U M O}

\section{Objetivo}

Estimar a proporção de sobrepeso em pessoas com Vírus da Imunodeficiência Humana /Síndrome da Imunodeficiência Adquirida e avaliar a associação do sobrepeso e do uso da terapia anti-retroviral de alta potência (Highly Active Antiretroviral Therap) com a presença de anormalidades metabólicas.

\section{Métodos}

Foi conduzido um estudo transversal entre pacientes ambulatoriais sob acompanhamento nutricional em um hospital universitário entre 2000-2006. A amostra incluiu 393 pacientes com Vírus da Imunodeficiência Humana/Síndrome da Imunodeficiência Adquirida. Foram usados registros nutricionais e registros médicos como fonte de dados sobre informações pessoais, clínicas e bioquímicas. A análise dos dados incluiu a estatística descritiva e o teste Qui-quadrado.

\section{Resultados}

Entre os pacientes, 69\% eram do gênero masculino, com idades entre 26 e 49 anos. Sobrepeso e obesidade foram identificados em $49 \%$ da população estudada. As complicações metabólicas mais importantes foram baixos níveis séricos de lipoproteína de alta densidade (70\%), altos níveis de triglicerídeos (48\%) e de colesterol (40\%). Um valor maior de índice de massa corporal estava associado aos altos níveis lipídicos e às evidências de resistência insulínica.

\section{Conclusão}

Este estudo identificou uma importante proporção de sobrepeso e obesidade entre indivíduos com Vírus da Imunodeficiência Humana/Síndrome da Imunodeficiência Adquirida. Estes resultados sugerem que as intervenções nutricionais e as mudanças do estilo de vida possam ser estratégias úteis para diminuir o risco cardiovascular nesta população.

Indexing terms: Sobrepeso. Obesidade. Dislipidemia. Resistência à insulina.

\section{NTRODUCTIO N}

The Acquired Immunodeficiency Syndrome (AIDS) epidemic in Brazil is widespread. The registered incidence rate in 2003 was of 20.7/ 100,000 inhabitants where 25.4/100,000 were males and 16.1/100,000 were females. The main health actions to control and prevent the epidemic have concentrated in the free and universal distribution of drugs and in the implementation of new preventive actions, which led to a significant reduction in mortality and increased survival of the patients ${ }^{1,2}$.

Currently, AIDS treatment reached important advances after the introduction of the highly active antiretroviral therapy (HAART), resulting in a more effective control of the infection, restoration of immunity and reduction of morbidity and mortality, turning AIDS into a chronic disease ${ }^{3}$. HAART must include at least 3 drugs: 2 nucleoside analog reverse transcriptase inhibitors (NARTIs) associated with a non- nucleoside reverse transcriptase inhibitor (NNRTI) or to a protease inhibitor $(\mathrm{PI})^{4}$.

It has been observed, however, that the treatment benefits have been accompanied by a number of side effects, especially metabolic and nutritional abnormalities, which are associated with a higher risk of early atherosclerotic complications ${ }^{5,6}$. Scientific evidences show that the main risk factors for the development of metabolic abnormalities associated with the use of antiretroviral drugs are: treatment duration, more advanced stages of the disease, and especially the use of certain drug classes, such as protease inhibitors $(I P)^{7}$.

One study points out that, when compared with the general population of same age range, patients with AIDS that use PI have a specific atherogenic profile, with elevated triglyceride rates and low HDL rates $^{8}$.

Other investigations have shown that, apart from the undesirable antiretroviral side effects, 
HIV + patients present a high rate of classical risk factors for the development of cardiovascular diseases and type 2 diabetes, such as inadequate eating habits, overweight, obesity, low level of physical activity and smoking ${ }^{9,10}$.

Recently, a North American study identified a high proportion of overweight and obesity in $\mathrm{HIV}+$ patients associated with bad eating habits and physical inactivity. The authors pointed out that excess weight in these patients can intensify metabolic abnormalities and cause the early development of cardiovascular diseases, thus systematic nutritional interventions need to be adopted to control weight during clinical HIV/AIDS treatment ${ }^{11}$.

A Brazilian study showed that, currently, obesity is the most important nutritional consequence among HIV/AIDS patients under HAART, outnumbering malnutrition ${ }^{12}$.

The objectives of this study were to estimate the proportion of overweight and assess the association of overweight and HAART use with metabolic abnormalities.

\section{METHODS}

A sample of adult individuals seen from 2000 to 2006 at the nutrition service of a university hospital of the city of Rio de Janeiro was included. All individuals that go to the institution for HIVIAIDS treatment are also seen at the nutrition service as well as those who seek dietary advice and those who are referred to the service by other health professionals. Individuals younger than 18 years, those older than 65 years and those whose medical records were incomplete were excluded from the sample.

Data were collected from the nutritional records of the unit which contain data regarding personal information, use of drugs, clinical information, family history, anthropometric data, food consumption and biochemical data obtained from medical records.

Personal data included age and gender, clinical data included use of HAART combined or not with protease inhibitors, T-CD4+ lymphocyte count and HIV viral load and biochemical data included levels of total cholesterol, HDLcholesterol, LDL-cholesterol, triglycerides and fasting glucose.

For information regarding life habits, the medical records were reviewed for current smoking status and amount consumed if positive ( $>10$ cigarettes/day) and use of alcoholic beverages in the last 6 months. The medical records were also consulted to determine their level of physical activity, gathering information on the practice of sports on a weekly basis or walks $(<3$ times or $>3$ times per week) and the time spent on activities such as watching TV or using the computer. Only short answers were used (yes or no).

The body mass index (BMI) was calculated as the ratio between the weight in kilograms $(\mathrm{kg})$ and the squared height in meters $\left(\mathrm{m}^{2}\right)$ according to the classification criteria proposed by the World Health Organization (WHO).

The software SPSS version 10.0 was used for the statistical analysis. The data were expressed as rates or means, standard deviation of the mean. Bivariate analyses using the chi-square test were done to compare the variables.

The variables were categorized into two groups: gender (male or female), age group (<39 years and $>40$ years), T-CD4+ lymphocyte count $\left(<200\right.$ and $>200$ cells $\left./ \mathrm{mm}^{3}\right)$, viral load $(<100000$ and $>100000$ copies $/ \mathrm{mL}$ ), cholesterol levels $(<200$ and $>200 \mathrm{mg} / \mathrm{dL}$ ), triglycerides $(<150$ and $>150 \mathrm{mg} /$ $\mathrm{dL}), \mathrm{HDL}$-cholesterol $(<40$ and $>40 \mathrm{mg} / \mathrm{dL}$ ), LDL-cholesterol $(<140$ and $>140 \mathrm{mg} / \mathrm{dL})$, glucose $(<126$ and $>126 \mathrm{mg} / \mathrm{dL})$ and body mass index (BMl< 24.9 or $>25.0 \mathrm{~kg} / \mathrm{m}^{2}$. The cut-off points used were those considered normal for the laboratory of the hospital unit under study. A fasting glucose level above $126 \mathrm{mg} / \mathrm{dL}$ was considered an indicator of diabetes mellitus.

Insulin resistance was determined by calculating the triglycerides/HDL ratio, as suggested by Reaven ${ }^{13}$.

The investigation was conducted after approval from the local ethics committee according 
to the Resolution 196/96 regarding research in human beings, $n^{\circ}$ 082/2006.

\section{RES U L T S}

A total of 393 patients seen at the nutrition unit from 2000 to 2006 participated in the study. Most were males (69.0\%) aging from 26 to 49 years $(75.3 \%)$ and had been using HAART for more than 3 years $(69.0 \%)$. Most of them $(74.0 \%)$ presented a T-CD4+ lymphocyte count above 200 cells $/ \mathrm{mm}^{3}$ and $39.0 \%$ presented viral load values that ranged from 50 to 80 thousand copies $/ \mathrm{mL}$. The characteristics of the studied sample are shown in Table 1.

Regarding lifestyle, $20.6 \%$ reported consuming alcoholic beverages in the last 6 months and $14.6 \%$ reported smoking more than 10 cigarettes per day. The vast majority (92.0\%) reported that they did not practice any sports or went for walks regularly, that is, $>3$ times per week.

Table 1. Characteristics of human immunodeficiency virus/ Acquired Immune Deficiency Syndrome patients being treated in the nutrition outpatient clinic of Rio de Janeiro (RJ) Brazil, 2000-2006.

\begin{tabular}{lcc}
\hline Variables & $\mathrm{n}$ & $\%$ \\
\hline Age range (years) & 32 & \\
18-25 & 296 & 75.3 \\
$26-49$ & 54 & 13.7 \\
$50-59$ & 11 & 2.8 \\
$>60$ & & \\
Gender & 122 & 31.0 \\
Female & 271 & 69.0 \\
Male & 300 & 76.3 \\
Taking antiretroviral drugs & 270 & 68.7 \\
HAART without protease inhibitors & 144 & 36.6 \\
HAART with protease inhibitors & & \\
T-CD4+ lymphocyte count (cells/mm ${ }^{3}$ ) & & \\
$<200$ & 53 & 13.5 \\
$>$ 200 & 298 & 75.6 \\
Not available & 42 & 10.9 \\
Viral load (copies/mL) & & \\
$<80$ & 116 & 29.5 \\
80-50 thousand & 154 & 39.2 \\
>50 thousand & 51 & 13.0 \\
Not available & 72 & 18.3 \\
\hline
\end{tabular}

The BMI distribution of the studied population shows that $35.4 \%$ are overweight and $13.7 \%$ are obese. Overall, $49.0 \%$ of the patients presented some degree of excess weight (Table 2).

A BMl above $25 \mathrm{~kg} / \mathrm{m}^{2}$ was significantly associated with the consumption of alcoholic beverages $(p<0.001)$. There were no significant differences between the distribution of overweight and obesity by gender, age group or practice of physical activity.

The biochemical parameters in the studied population consisted of high triglyceride means (204.3 standard deviation - SD $9.01 \mathrm{mg} / \mathrm{dL}$ ) and low levels of HDL-cholesterol (29.2 SD $1.07 \mathrm{mg} / \mathrm{dL}$ ). An important proportion of the patients had triglyceride levels above $150 \mathrm{mg} / \mathrm{dL}(48 \%)$ and $70 \%$ presented $\mathrm{HDL}$-cholesterol levels below $40 \mathrm{mg} / \mathrm{dL}$.

A triglyceride/HDL-cholesterol ratio $>3$ was seen in $61 \%$ of the overweight and obese patients (Table 3).

Table 2. Distribution of the body mass index of human immunodeficiency virus/Acquired Immune Deficiency Syndrome patients of a University Hospital of Rio de Janeiro (RJ) Brazil, 2000-2006.

\begin{tabular}{lcc}
\hline Body mass index range $\left(\mathrm{kg} / \mathrm{m}^{2}\right)$ & $\mathrm{n}$ & $\%$ \\
\hline$<18.5$ & 24 & 6.1 \\
$18.5-24.9$ & 176 & 44.8 \\
$25.0-29.9$ & 139 & 35.4 \\
$>30$ & 54 & 13.7 \\
\hline
\end{tabular}

Table 3. Biochemical parameters of human immunodeficiency virus/Acquired Immune Deficiency Syndrome patients of a University Hospital of Rio de Janeiro (RJ) Brazil, 2000-2006.

\begin{tabular}{lcccc}
\hline \multirow{2}{*}{ Parameters $(\mathrm{mg} / \mathrm{dL})$} & \multirow{2}{*}{ M } & SEM & \multicolumn{2}{c}{ Values } \\
\cline { 5 - 6 } & & & $\mathrm{n}$ & $\%$ \\
\hline Total cholesterol $>200$ & 187,0 & 3.40 & 159 & 40.5 \\
Triglycerides $>150$ & 204.3 & 9.01 & 189 & 48.1 \\
Glucose $>126$ & 78,0 & 2.12 & 16 & 4.1 \\
HDL-cholesterol $<40$ & 29.2 & 1.07 & 275 & 70,0 \\
LDL-cholesterol $>140$ & 75.82 & 3.39 & 71 & 18.1 \\
TG/HDL in patients with BMI ${ }_{12}^{24} 25 \mathrm{~kg} / \mathrm{m}^{2}>3$ & 81 & 61.4 \\
\hline
\end{tabular}

SEM: standard error of the mean; M: mean; LDL: low density lipoprotein; HDL: high density lipoprotein; TG: triglycerides; BMI: body mass index. 
Table 4. Metabolic abnormalities according to the presence of excess weight and use of antiretroviral drugs in HIVIAIDS patients of a University Hospital of Rio de Janeiro (RJ) Brazil, 2000-2006.

\begin{tabular}{|c|c|c|c|c|c|c|}
\hline \multirow{3}{*}{ Abnormalities } & \multicolumn{2}{|c|}{$\%$ HAART w/o PI } & \multicolumn{2}{|c|}{$\%$ HAART w/PI } & \multicolumn{2}{|c|}{ \%Overweight/Obesity } \\
\hline & Yes & No & Yes & No & Yes & No \\
\hline & $\rightarrow$ & $\leftarrow$ & $\rightarrow$ & $\leftarrow$ & $\rightarrow$ & $\leftarrow$ \\
\hline Cholesterol >200mg/dL & 46.5 & $27.6^{*}$ & 54.9 & $32.1^{*}$ & 47.2 & $34.0 * *$ \\
\hline Triglycerides >150mg/dL & 55.9 & $30.9^{*}$ & 56.9 & $43.0 * *$ & 53.4 & $43.0^{* *}$ \\
\hline Glucose $>126 \mathrm{mg} / \mathrm{dL}$ & 4.1 & 4.1 & 5.6 & 3.2 & 6.7 & $1.5^{* *}$ \\
\hline HDL-chol <40mg/dL & 64.1 & 82.9 & 64.6 & 73.1 & 69.4 & 70.5 \\
\hline LDL-chol >140mg/dL & 20.7 & $12.2 * *$ & 27.1 & $12.9^{* *}$ & 18.7 & 17.5 \\
\hline
\end{tabular}

${ }^{*} p<0.001 ;{ }^{* *} p<0.05$; LDL: low density lipoprotein; HDL: high density lipoprotein; TG: triglycerides; HAART w/o PI (highly active antiretroviral therapy without protease inhibitors); HAART W/PI (highly active antiretroviral therapy with protease inhibitors).

The presence of biochemical abnormalities was significantly influenced by the use of HAART and especially, by the use of protease inhibitors: high levels of cholesterol $(p<0.001)$, triglycerides $(p<0.001)$ and LDL-cholesterol $(p<0.001)$ were observed. Associations between the use of antiretroviral drugs and HDL-cholesterol or glucose were not observed. BMI in the overweight/obesity ranges significantly influenced the high levels of cholesterol $(p<0.05)$, glucose $(p<0.05)$ and triglycerides $(p<0.05)$ (Table 4$)$.

\section{DISCUSSION}

The results of this study allowed the identification of a proportion of roughly $50.0 \%$ of some degree of excess weight in the assessed population. Obesity was found in $13.0 \%$ of the patients. Another Brazilian study identified an excess weight proportion of $30.5 \%$ in an HIV+ population ${ }^{12}$.

These data point toward a growing overweight and obesity problem in this population, which can be explained by increased survival and reduced occurrence of opportunistic diseases after the use of highly active antiretroviral therapies ${ }^{11}$. Excess weight is an aggravating condition in the development of dyslipidemias, insulin resistance and early atherosclerotic complications ${ }^{14}$.

Generally, the main biochemical abnormalities identified were low levels of HDL-cholesterol (70.0\%) and high levels of triglycerides (48.0\%) and total cholesterol (40.0\%). These abnormalities were significantly associated with the use of HAART with or without the concomitant use of protease inhibitors.

Even though all the mechanisms implied in the development of metabolic abnormalities associated with HIV/AIDS treatment are unknown, many authors emphasize that there is a strong contribution of antiretroviral drugs in this process $^{7,8,15.16}$.

In this study, the presence of overweight and obesity was significantly associated with high levels of total cholesterol, triglycerides and glucose. A previous study ${ }^{17}$ evidenced that, in general, higher BMI values are frequently associated with high lipid levels and a stronger evidence of insulin resistance in HIV+ patients.

Obesity favors the development of the metabolic syndrome (MS) and there is a positive, linear association between $\mathrm{BMI}$ and triglyceride levels and an inverse association between BMI and HDL-cholesterol levels. This suggests that excess weight can directly favor the development of MS components ${ }^{18}$.

According to Reaven ${ }^{13}$, a triglyceride/HDL ratio $>3$, although not a perfect measurement, is considered a strong indicator of insulin resistance and poses a high risk of type 2 diabetes and cardiovascular diseases.

In the present study, $61 \%$ of the overweight and obese patients presented a triglyceride/HDL ratio $>3$, suggesting insulin resistance. 
Insulin resistance is the main MS component and when it is associated with other risk factors such as hypertension and abdominal obesity, it defines a pre-diabetic and atherogenic state than can lead to the onset of cardiovascular events $^{19}$.

Other investigations have reported that nutritional and lifestyle interventions are beneficial for the metabolic abnormalities associated with the use of antiretroviral drugs, and can be used as useful strategies to reduce cardiovascular risk in this population ${ }^{20,21}$.

This study evidenced a high proportion of overweight and obesity in the group of HIV/AIDS patients studied. The metabolic abnormalities were more common in patients using antiretroviral drugs and in the overweight and obese. These results suggest the need to monitor body weight, food consumption and cardiovascular risk factors associated with overweight and obesity regularly when dealing with HIVIAIDS patients.

The limitations of this study are associated with the fact that only the patients seen in the nutrition service of the institution were assessed, and this may not reflect the profile of all HIV/AIDS patients being treated in our hospital unit. Another limitation refers to the fact that the data were collected directly from the records. However, the collected information will serve as a base for the development of a future, broader investigation to be done by our research team which will involve a significant sample of all patients of this hospital unit in order to determine the magnitude of the metabolic complications seen in this population and establish a cardiovascular risk surveillance system specifically for these patients.

\section{COLLABORATORS}

L.H.M. LEITE did the bibliographic review, collected data, performed the statistical analysis and discussed the results. A.B.M.M. SAMPAIO collaborated for the bibliographic review, analysis and discussion of the results. All authors collaborated for the final version of the article.

\section{R E F E R E N C E S}

1. Brasil. Ministério da Saúde. Secretaria de Vigilância em Saúde. Programa Nacional de DST e Aids. Bol Epidemiol Aids e DST. 2006; 3(1)3-4.

2. Egir E, Vaichulonis CG, Oliveira MD. Adesão à terapêutica anti-retroviral por indivíduos com HIV/AIDS assistidos em uma instituição do interior paulista. Rev Latino-Am Enfermagem. 2005; 13(5):634-41.

3. Portela MC, Lotrowska M. Assistência aos pacientes com HIVIAIDS no Brasil. Rev Saúde Pública. 2006; 40(Supl 1):70-9.

4. Brasil. Ministério da Saúde. Secretaria de Vigilância em Saúde. Programa Nacional de DST e Aids. Recomendações para a terapia anti-retroviral em adultos e adolescentes infectados pelo HIV. 6 ed. Brasília; 2006. Série Normas e Manuais Técnicos.

5. Barbaro G. Reviewing the cardiovascular complications of HIV infection after the introduction of highly active antiretroviral therapy. Curr Drugs Targests Cardiovasc Haematol Disord. 2005; 5(4):337-43.

6. Yu PC, Calderaro D, Lima EMO, Caramelli B. Terapia hipolipemiante em situações especiais: síndrome da imunodeficiência adquirida. Arq Bras Cardiol 2005; 85(Suppl 5):58-61.

7. The data collection on adverse events of anti-HIV drugs (DAD) study group. Combination antiretroviral therapy and the risk of myocardial infarction. New Eng J Med. 2003; 349(21): 1993-2003.

8. Savès $M$, Chêne $G$, Ducimetiere $P$, Leport $C$, Le Moal $G$, Amouyel $P$, et al. Risk factors for coronary heart disease in patients treated for human immunodeficiency virus infection compared with the general population. Clin Infect Dis. 2003; 37(2):292-8.

9. Thiébaut $R$, Savès $M$, Mercié $P$, Cipriano $C$, Chêne $G$, Dabis F. Épidémiologie du risque vasculaire d'origine athéroscléreuse chez les patients infectés par le VIH-1. Presse Med. 2003, 32(30):1419-26.

10. Jacobson DL, Tang AM, Spiegelman D, Thomas AM, Skinner S, Gorbach SL, et al. Incidence of metabolic syndrome in a cohort of HIV-infected adults and prevalence relative to the US population (National Health and Nutrition Examination Survey). J Acquir Immune Defic Syndr. 2006; 43(4): 458-66.

11. Hendricks KM, Willis K, Houser R, Jones CY. Obesity in HIV-infection: dietary correlates. J Am Coll Nutr. 2006, 25(4):321-31.

12. Jaime $P C$, Florindo $A A$, Latorre $M R D O$, Brasil $B G$, Santos ECM, Segurado AAC. Prevalência de sobrepeso e obesidade abdominal em indivíduos 
portadores de HIV/AIDS, em uso de terapia anti-retroviral de alta potência. Rev Bras Epidemiol. 2004; 7(1):65-72.

13. Reaven GM. The insulin resistance syndrome: definition and dietary approaches to treatment. Ann Rev Nutr. 2005; 25(1):391-406.

14. Visnegarwala F, Raghavan SS, Mullin CM, Bartsch G, Wang J, Kotler D, et al. Sex differences in the association of HIV disease characteristics and body composition in antiretroviral naïve persons. Am J Clin Nutr. 2005; 82(4):850-6.

15. Chêne G. Risque cardiovasculaire et VIH. Impact des traitements antirétroviraux. La lettre de I'Infectiologue. 2004; 2(mars-avril):4-5.

16. Barbaro G, Klatt EC. Highly active antiretroviral therapy and cardiovascular complications in HIVinfected patients. Curr Pharm Des. 2003; 9(18): 1475-8.

17. El-Sadr WM, Mullin CM, Carr A, Gilbert C, Rapport C, Visnegarwala F, et al. Effects of HIV disease on lipid, glucose and insulin levels: results from a large antiretroviral naïve cohort. HIV Med. 2005; 6(2): 114-21.

18. Delarue J, Allain G, Guillerm S. Le syndrome métabolique. Nutr Clin Met. 2006; 20(2):114-7.

19. Shikuma CM, Day LJ, Gerschenson M. Insulin resistance in the HIV-infected population:the potential role of mitochondrial dysfunction. Curr Drug Targets Infect Disor. 2005; 5(3):255-62.

20. Fitch KV, Anderson EJ, Hubbard JL, Carpenter SJ, Waddell WR, Caliendo AM, et al. Effects of a lifestyle modification program in HIV-infected patients with metabolic syndrome. AIDS. 2006; 20(4):1843-50.

21. Davidson $\mathrm{MH}$. Management of dyslipidemia in patients with complicated metabolic syndrome. A J Cardiol. 2005; 96(4A):22E-5E.

Received on: 12/4/2007

Final version resubmitted on: $26 / 3 / 2008$

Aproved on: 2/4/2008 